\title{
The Effectiveness and Importance of Leg-Foot Massage
}

\author{
Satoshi Sasada* \\ Department of Occupational Therapy, Kanagawa University of Human Services, Japan
}

Submission: March 14, 2017; Published: April 27, 2017

*Corresponding author: Satoshi Sasada, School of Rehabilitation,Department of Occupational Therapy, Kanagawa University of Human Services,Kanagawa,Yokosuka,Japan,Email: sasada@kuhs.ac.jp

\section{Opinion}

Humans often unconsciously rub the left and right hands together at the center of the body and massage the left and right feet. The development of the foot is observed in the baby's movement. The baby develops the soles of both legs in 6 months. Thus, massage of the foot seems a human instinct.We focused on the gesture of people rubbing their feet and developed a method of foot-leg exercise. We examined the effect of foot-leg exercise, which consists of three methods, namely parallel, cross, and sandwich. Details of the methods are as follows:

\section{Parallel}

The subject sits straight on a chair and moves the sole (arch of the foot) up and down for approximately $15 \mathrm{~cm}$ along the inside lower part of the other leg (Figure 1).

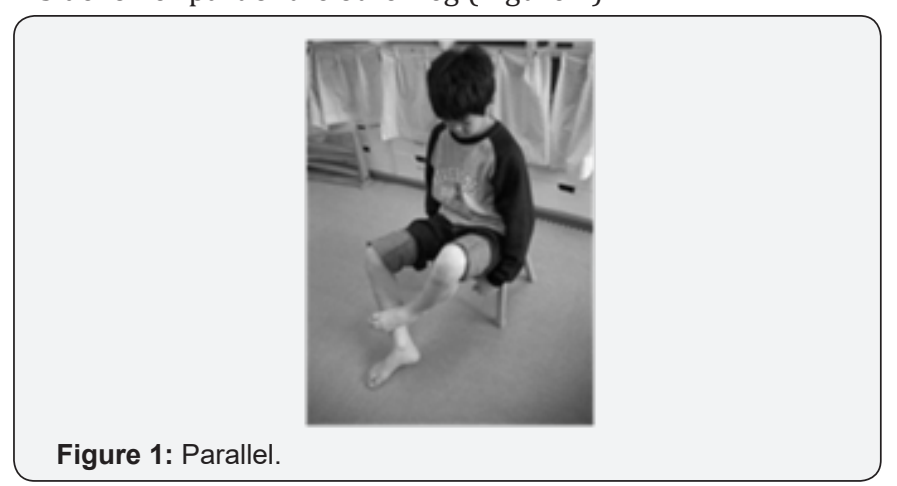

\section{Cross}

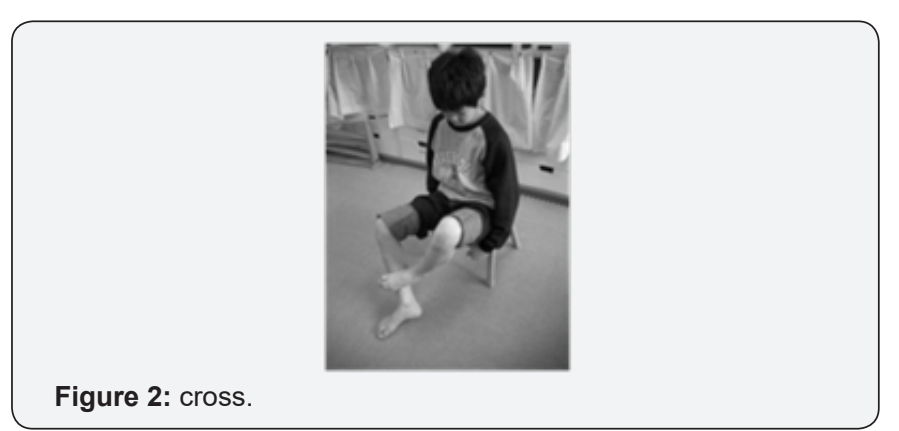

The subject bends the neck slightly to see the lower limbs. The back of the foot is moved up and down along the outside lower part of the other leg for $15 \mathrm{~cm}$ (Figuer 2).

\section{Sandwich}

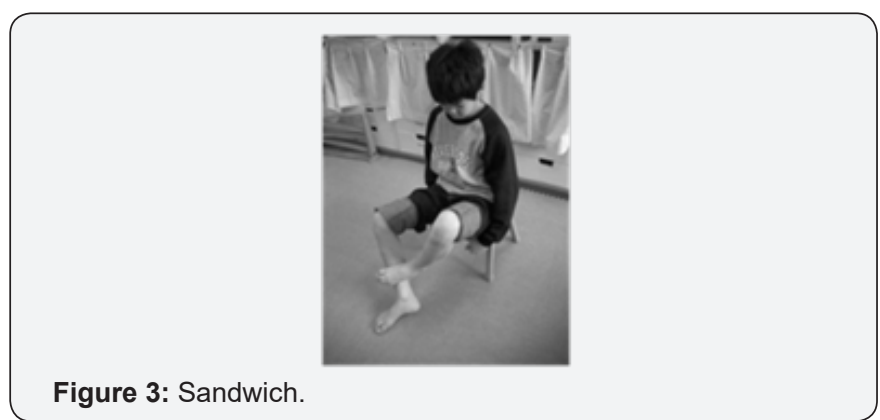

The subject bends the neck slightly to see the lower limbs and loosen up the upper limbs. Achilles's tendon of the other leg is fastened by using the big and second toes, moving up and down $5 \mathrm{~cm}$ from the heel (Figure 3). When doing the sandwich exercise, the fingers are stretched to spread the thumb and second fingers (Figure 4). At the same time, Achilles's tendon is massaged.The subjects were menopausal women with foot pain and poor circulation.After three exercises, the subjects reported a positive change in their moods [1]. Not only their physical symptoms but also their mental states were improved by the exercise [2-4]. These results indicate that our method of foot-leg massage has a positive effect.

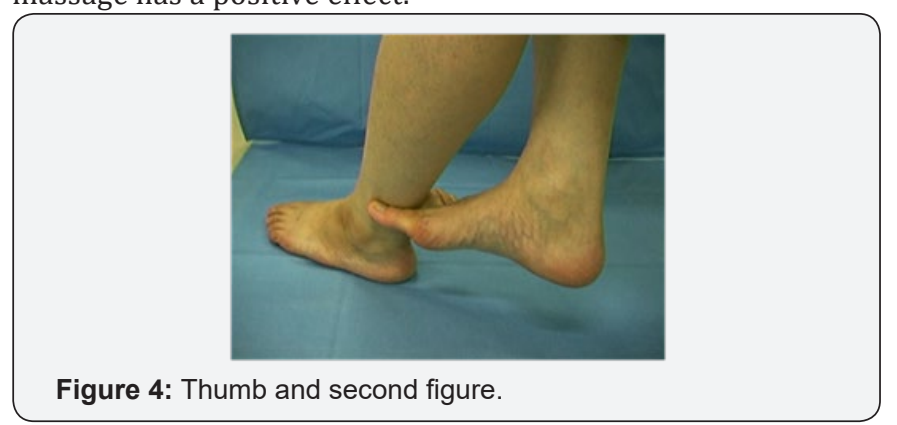


Furthermore, our results demonstrate that this gymnastic exercise is also effective for children with developmental disorders. A therapist visited an elementary school and applied foot-leg exercise to students in a physical education class $[5,6]$. The students considered the foot-leg exercise as easy to perform and not burdensome to the legs. From the viewpoint of risk management, the exercise was safe and, despite the easy movement, was effective for maintaining the personal health of the elementary school students in a special-needs class [7]. As a result, the studentscould now wash their toes and wear socks on their own. The foot-leg exercises have much in common with the contact points in yoga. I think that a new therapy combined with yoga is possible. We would like to examine the approach in the future.

\section{References}

1. Morishita S, Miyajima N, Sasada S, Yashiro A (1999) Research Effect of self-care exercise for a pain of the lower limbs caused by a symptom of menopausal disorders. Journal of Comprehensive Nursing, 2(1): 25-35.
2. Sasada S, Yashiro A, Morishita S, Aoki K (1997) A study on development of self care physical exercises for women past middle age. Japanese Journal of Ergonomics 33: 152-153.

3. Sasada S, Yashiro A, Morishita (1998) A study on method of self care for climacteric symptoms; Theachilles' tendon and range of ankle joint. Journal of Comprehensive Nursing Research 1(2): 34-37.

4. Sasada S (1999) The development of self care exercise for pains of the lower extremities as symptoms of menopausal disorder. The $9^{\text {th }}$ International Menopause Society World Congress on the Menopause, Monduzzi Editore, Bologna, Italy pp. 373-377.

5. Sasada S (2000) Analysis on the Physical Education Class for Pupils in the Special Class-From the Viewpoint of the Sensory Integration Model. The Journal of Japan Academy of Health Sciences 3(2): 126-129.

6. Sasada S (2009) Practice of community based rehabilitation to the children with mental retardation in the special class of the elementary school. The 5th World Congress of the International Society of Physical and Rehabilitation Medicine, Edizioni Minerva Medica, Italy pp. 109110.

7. Nachemson A, Evans J (1968) Some mechanical properties of the third human lumber inter laminar ligament (ligament flavum). J Biomech 1(3): 211-220.

\section{Your next submission with Juniper Publishers} will reach you the below assets

- Quality Editorial service

- Swift Peer Review

- Reprints availability

- E-prints Service

- Manuscript Podcast for convenient understanding

- Global attainment for your research

- Manuscript accessibility in different formats ( Pdf, E-pub, Full Text, Audio)

- Unceasing customer service

Track the below URL for one-step submission https://juniperpublishers.com/online-submission.php 